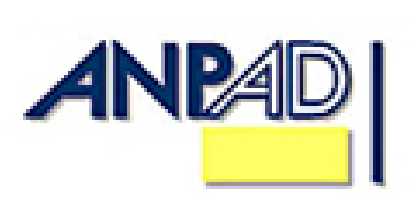

Notas Bibliográficas:
Disponível em http://www.anpad.org.br/rac

RAC, Curitiba, v. 15, n. 3 , p. 560, M aio/J un. 2011

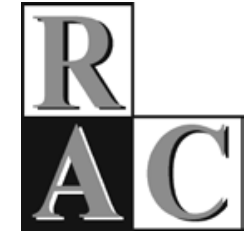

$(\infty)$ EY-NG

\section{A PSICOLOGIA DO LÍDER}

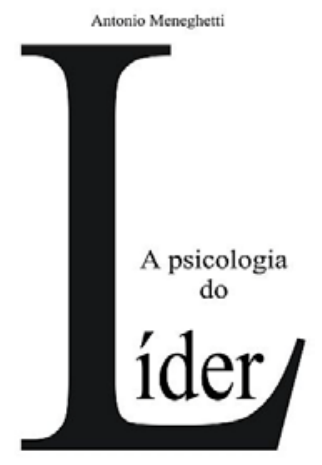

De Antonio $M$ eneghetti. Recanto $M$ aestro: Ontopsicologica Editrice, 2008. 323 p. ISBN 978-85883-81-42-1

Está é a 4a edição, revisada e ampliada, de um livro no qual seu autor, profundo conhecedor da psique humana, aborda 0 vasto mundo subjetivo da pessoa do líder. A través dos critérios utilizados por A ntonio Meneghetti é possível dissecar os aspectos comumente transcendidos quando se aborda o assunto da liderança. Por meio da exposição de quem é o líder e de que modo o seu mundo íntimo atua seja no sucesso que no fracasso, Meneghetti evidencia que na origem de todo fato econômico, político ou social encontra-se uma motivação psicológica, geralmente oriunda do inconsciente do líder. Demonstra também que no mesmo inconsciente existe um núcleo inteligente que impulsiona o sujeito às escolhas certeiras e ao consequente êxito. Para diferenciar uma coisa da outra, o autor apresenta a metodologia e os instrumentos que possibilitam uma leitura exata das motivações inconscientes. U ma obra indispensável para o estudo da liderança e um guia inestimável para lideres de todas as áreas de atuação.

Nota por A driane M. M . M endes. UFSC, Florianópolis/SC, Brasil.

E-mail: adriane@egc.ufsc.br

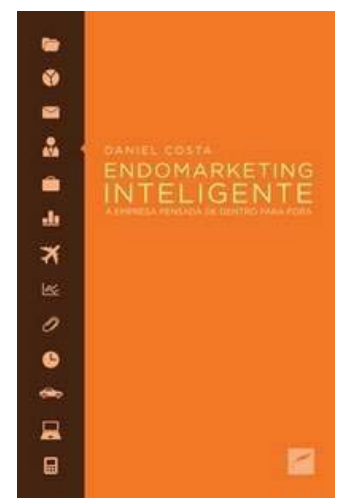

ENDOMARKETING

INTELIGENTE:

a Empresa Pensada de Dentro para

Fora

De Daniel Costa. Porto A legre: Dublinense, 2010. 144 p. ISB N : 978-85-62757-17-4

A obra lançada pelo autor Daniel Costa propõe à empresa a importância dela se auto conhecer e perceber 0 que os seus colaboradores pensam da organização. 0 autor traça um histórico das organizações e a evolução das abordagens motivacionais e os seus impactos no clima organizacional. o livro expõe que é imprescindível para a empresa comunicar-se de forma eficiente com o seu público interno. A qualidade do relacionamento que a empresa estabelece com os seus colaboradores irá refletir no nível de sucesso que ela alcançará no mercado em que atua. 0 livro se destina a acadêmicos e profissionais das áreas de comunicação, marketing e recursos humanos. Os conceitos e técnicas apresentados na obra podem ser aplicados no planejamento e execução de sistemas de endomarketing e comunicação interna.

Nota por M urilo M artins A ndrade.

UFPR, Curitiba/PR, B rasil.

E-mail: murilofacear@hotmail.com 